\title{
The Communist Party of Slovakia between the liberation and the gain of totalitarian power
}

\section{MAREK SYRNÝ}

Department of History, Faculty of Arts, Matej Bel University, Banská Bystrica, The Slovak Republic e-mail: marek.syrny@umb.sk

\begin{abstract}
This study deals with the tactics, means and methods by which the Communist Party of Slovakia, as a regional branch of the Czechoslovak Communist Party, politically fought for a monopoly of power after the Second World War. First, it briefly describes the development of this party and its acceptance by the Slovak society in the interwar and war period. Then, it presents a picture, analyses and compares the ways in which the Slovak Communists tried to disqualify their insurgent partners and post-war rivals for power in the political struggle the Slovak Democrats. It notes the relations between the Slovak and Czech Communists, the transformation of communist propaganda and tactics, conditioned by a single goal - the gain of totalitarian power, the introduction of the dictatorship of the proletariat and the replacement of capitalism by communism. Until the communist takeover in Czechoslovakia in February 1948, the Communists used a variety of democratic, semi-democratic and outright violent and undemocratic practices to win - from hyperbolizing the party propaganda, via the abuse of mass social organizations and the secret police, to purposeful investigation and intimidation and the threat of using a forceful solution of the political struggle. ${ }^{1}$
\end{abstract}

\section{Keywords:}

Czechoslovakia after World War II, Communist Party of Slovakia (KSS),

Democratic Party (DS), political fight, democracy, totalitarian power

1 This study is the result of an institutional research of Faculty of Arts, Matej Bel University in Banská Bystrica. 


\section{Slovak Communists until 1945}

When Slovak Communists entered the new post-war era at the already liberated territories of Eastern Slovakia in early 1945, they had earlier experiences from two significant periods: the foundation and interwar era of the First Czechoslovak Republic and the equally dynamic stage of a more autonomous existence in the Slovak State. Both of these previous periods influenced the post-war development and "mentality" of the Communist Party of Slovakia (Komunistická strana Slovenska, KSS) significantly, not only within the Party, but especially in the perception of the Communists by the Slovak society.

The existence of Slovak Communists - as the regional branch of the Communist Party of Czechoslovakia (Komunistická strana Československa, KSČ) in the era of the First Czechoslovak Republic (1918-1938) does not seem to be less significant or fruitful than their existence during later periods. Although the Communists were, due to their radical social views, a politically isolated group in terms of cooperation with other parties or in terms of acceptance by other opinion groups in the population, they were relatively successful. After all, they were always able to reach at least to $14 \%$ of the electorate in the elections in Slovakia, which ranked them among the $3^{\text {rd }}$ and $4^{\text {th }}$ most successful parliamentary parties. The electoral or even coalition potential of Slovak Communists was obviously negatively limited despite the clear advantages of flexible, sometimes unscrupulous political tactics and the firm emphasis on the radical solution of social issues. Even a later focus on a possible solution of the Slovak question, demanding autonomy or federalization, could not take the Party out of the shadow of the dominant Hlinka's Slovak People's Party (Hlinkova slovenská ludová strana, HSL'S). The Party used similar social and national populistic tactics in order to win the Slovak electorate over, although focusing more strictly on the attacks against the Czechs, contrary to the more general Communist struggle against world capitalism and imperialism. The development of the Communist movement in Slovakia was also limited by the low numbers of workers in the social structure, while the Slovak industry was far behind when compared to that in the Czech Lands. Along with the overall weak development of political and social life in Slovakia, in contrast to the situation in Bohemia and Moravia, it was only natural that the Party headquarters in Prague had to send many instructors and authorise functionaries in order to build an operational organisation of the Party in Slovakia to be able to operate at least partially. ${ }^{2}$ Klement Gottwald and Karol Šmidke were among the most famous Czech, or rather Moravian, functionaries who spent a part of their interwar Party activities in Slovakia.

2 See LIPTÁK, Lubomír a kol.: Politické strany na Slovensku 1860 - 1989 (Political Parties in Slovakia, 1860-1989). Archa, Bratislava 1992, pp. 181-184. 
Due to small numbers of industrial workers, the Communists in Slovakia had to focus more on addressing agricultural workers. There, however, they encountered the influence of the HSL'S and the inclination of the majority of the farmers to the Agrarian Party - the political party closest to their occupation. On the one hand, the pre-war Slovak Communists had many possibilities to win the majority of the Slovak society over or, at least, to be perceived as a less dismissive and anti-establishment party. Especially in the 1930's, they came closer and closer to the ideals of the autonomist bloc with their solution to the Slovak question. They were also open to a close cooperation with the opposition against the Prague centralism of the ruling Czech bourgeoisie. On the other hand, when the Czechoslovak Republic was threatened by Nazism and after the signing of the Czechoslovak-Soviet treaty of 1935, the acceptance of the Communists by the governing parties and their electors significantly increased. After the Western Powers ignored the rescue pleas from Prague during the 1938 crisis, the creation of an overall successful illusion of a unique determination of the Soviet Union to provide military help to Czechoslovakia in need was almost done.

Slovak Communists entered the new era of post-Munich period with a relatively decent political potential. Despite their de facto autonomist past during early stages of a new autonomous Slovakia, the Communists encountered strong rejection by the authoritarian conservative HSL'S, which strictly rejected all leftists. The Communist movement was outlawed as early as October 1938 and was gradually officially pushed out of public life. However, the next almost 6 years of illegality did not bring only negative effects to Slovak Communists. Quite the opposite.

After the initial weak steps taken by the L'udák regime (regime of the HSLS, similar to a radical nationalist version of the Christian Democratic Party) against the opposing Communists in illegality, a de facto existential struggle to maintain the Communist movement and illegal structures of the Party in Slovakia started after the German invasion of the Soviet Union. Only after the decimation of the first four illegal Central Committees and regional structures of the Party attached to them and the arrest of thousands of Communists was there a more successful period that started in 1943 when the organisational degeneration ceased and the social and political programme of the Slovak Communists spread.

The division of Czechoslovakia resulted in the complete organisational and programme independence of the Slovak part of the Communist Party of Czechoslovakia. A period of searching for new, less experienced Slovak members and newer programmes to replace the previous interventions from the Prague party headquarters started. However, the establishment of the sovereign Communist Party of Slovakia in May 1939 also helped Slovak Communists "to mature". Without the possibility of clear instructions from Moscow or Prague, independent party programmes and tactics on how to eradicate capitalism and establish Communist rule 
in Slovakia evolved. Gradually, starting with the vision of a Soviet Slovakia ${ }^{3}$ in 1943, the Communist Party of Slovakia wanted to rebuild Czechoslovakia on the basis of significant economic, social, political and national reforms. In the summer and autumn of 1943, Slovak Communists and the non-Communist resistance of the dominant Agrarian Party (Republikánska strana zemedělského a malorolníckeho lidu) reached virtually the same programme agreement as the exiles in the centres of London and Moscow. The Slovak National Council (Slovenská národná rada, SNR) was formed, and a nationwide uprising was prepared with the equal participation of both the Communist and non-Communist (i.e., pro-Czechoslovak and pro-Democratic) sections of the resistance. For the first time in Slovak history, the Communist Party of Slovakia gained governmental posts. Slovak Communists participated at ruling over the insurgent Slovakia and gained the widest possible social awareness. The previously ostracized political alternative became an accepted political partner. Many even considered the Communists to be the future main political force in Slovakia. The three-to-five-thousand members of the KSS were quickly joined by new members and supporters during the war. Communist influence was politically dominant in numerous partisan organisations; they controlled the Provisional Ministry of Interior and were able to influence the adoption of new insurgent revolutionary legislation. The unification of the Social Democrats and the KSS in September 1944 on the basis of the Communist Party was one of their greatest successes. By the absorption of the then less significant Social-Democratic bloc, Slovak Communists also achieved strategically important unprecedented control of the trade unions. Despite the later military defeat of the Slovak National Uprising (Slovenské národné povstanie, SNP), which lasted from $29^{\text {th }}$ August till the end of October 1944, the Communists ended the war as a socially respected governmental/coalition force. The Communist Party of Slovakia was admired because of repressions and the losses its members suffered during the L'udák regime and Nazi occupation. It had great authority thanks to the entry of the Soviet Union and the Red Army into Central Europe. It was also respected by its political partners from the Slovak National Council because of its consensual approaches during the joint insurgent governance. It gained wide social sympathies because of its political, social and national programme (fight against fascism, equal rights for Slovaks and Czechs, socialisation in the economy and the society, stronger representation of the common people in the state administration, etc.). On the outside, Slovak Communists clearly rejected slogans and procedures that were tactically too radical. They rather came up with a more moderate social-

3 This vision was at the most included in the KSS programme from May 1941, when the Soviet boundaries was only few tens of kilometres from the Slovak state. This vision was based on the possibility of the creation of Communist (Soviet) Slovakia (a dictatorship of the proletariat, nationalization of the business private property etc.) in the case of geopolitical changes (like it was before in Eastern Poland after the changes based on the Ribbentrop-Molotov Pact), or if the Ludák regime collapsed in an internal social revolution. 
-democratic programme of public socialisation. In their subconscious, however, they were constantly planning a successful political march to absolute power and a total reconstruction of the society. ${ }^{4}$

\section{Slovak Communists in the first post-war year}

The Red Army and the $1^{\text {st }}$ Czechoslovak Army Corps (Prvý československý armádny zbor v Zväze sovietskych socialistických republík) ${ }^{5}$ liberated the first major areas of Eastern Slovakia already in the last months of 1944. The beginning of a new political and social organisation in this area, which had been the site of fierce battles a few weeks prior, started in January or February 1945. At the beginning of the liberation, the Czech and the Slovak Communists had a great vision of gradual socialisation and later communisation of the country. Czechoslovakia was liberated from the east by the Soviets and it was uncertain whether the Western armies would ever reach its territory by the end of the war. The main condition for Communist dominance in the post-war period in a form of a great power "shield and sword" of Soviet hegemony in Central Europe was fulfilled. Additionally, domestic Communists were among the main resistance forces. It was impossible to imagine a post-war government in the Czech Lands or in Slovakia without them. Nevertheless, nothing would hamper a sharper and less cautious socialisation or even the Sovietisation of the country. However, the chairmanship of the Czechoslovak Communists in Moscow, as well as their Soviet mentors and patrons, was well aware of the tactical inappropriateness of a rapid beginning of Communist governmental domination. It was not even clear how the Western Powers would react to Soviet dominance in the area, nor how the inhabitants of the state, raised in the Czechoslovak First Republic's Masaryk democracy and relative economic and social prosperity would react to Communism and the Communists. Furthermore, regarding the pre-war behaviour of the democratic regime towards the Communist Party, unlike the authoritarian regimes in this territory, there were initially no obvious reasons to go into sharp conflict with the "bourgeoisie". To eliminate the right-wing (almost fascist) bourgeoisie, which ruled or collaborated with the German Reich during the war, the KSS would be satisfied with administering justice in a form of trials and depriving the right-wing bourgeoise of its material base by nationalising its banks, companies or land. Moreover, the resistance bourgeoisie was not hostile to the Communists. On the contrary, good relations with foreign resistance led by President Edvard Beneš and the cooperation of the democratic resistance with the

4 SYRNÝ, Marek: Slovenskí komunisti v rokoch 1939 - 1944 (Slovak Communists in 1939-1944). Belianum, Banská Bystrica 2013, pp. 11-185.

5 The Czechoslovak exiled army corps in Soviet Union gradually created between 1942 and 1944 as part of the Czechoslovak Army in exile, personally under the command of the exiled military authorities (Czechoslovak Ministry of Defence), but operationally under the Soviet command. In the said period, it had almost 20,000 members. 
Communists at the time of common existential threat caused quite long-lasting cooperation of the Czech or Slovak Communists with non-Communist parties and politicians in the post-war governments.

The obvious advantage of the Slovak Communists was the fact that they were the ones who had the upper hand strategically and tactically, the ones who had powerful tutors and advisers in Moscow. They advised Gottwald, and he, in turn, advised the Slovak Communists, whom he sporadically met in Moscow, to be cautious, calm, less radical, and to choose the tactics of gradual, slow socialisation and communisation. ${ }^{6}$ This stage of the Communist route to power was later named the "National-Democratic Revolution" (Národno-demokratická revolúcia). In the non-propaganda translation this meant a steady (factually non-revolutionary and certainly non-violent) transition from capitalism to socialism at the time also known as a "people's democracy". Ironically, this mixture of democracy and undemocratic elements, capitalism and socialism, suited both sides of the later existential political struggle - the Slovak Communists as well as the Slovak Democrats (Demokratická strana, DS) 7 . It provided the Communists with the possibility of a non-violent rule and political initiative, control over decisive means of power and, with the necessary cooperation with the "bourgeoisie", achieving a rapid post-war reconstruction of the country. ${ }^{8}$ This allowed ("in a good way" and non-violently) to convince the population about the benefits of socialism, the nationalisation of the decisive industry or banks, equalisation of social differences, etc. On the other hand, for the Democrats or non-Communist politicians in the Czech lands and in Slovakia this political-power "pact" did not take away the opportunity to defend at least the main attributes of democracy and freedom and to avoid complete or violent communisation and Sovietisation. Either way, the political equation about the actual influence on the post-war development of the state remained unbalanced, Klement Gottwald, the chairman of the Communist Party and the Deputy Prime Minister, expressed it very concisely when addressing the forthcoming post-war coalition government with democratic non-Communists in the sense that: We need each other, but they need us more than we need them...

All other steps of the Slovak Communists resulted from this publicly insignificant but internally always immanently omnipresent Communist power domination. Unlike the Slovak Democrats, the Communists started energetically, and they were the first to be politically active and organised in the liberated districts. They could afford to organise district and regional conferences a few weeks after the

6 Národní archiv České republiky (National Archive of the Czech Republic, hereinafter only NA), f. (Fund) Klement Gottwald (100/24), sv. (Volume) 173, a. j. (Archival unit) 1543.

7 Slovak political party created during the Slovak National Uprising integrating all non-Communist centre and right-wing political groups.

8 Compare for example VARTÍKOVÁ, Marta (ed.): Komunistická strana Slovenska. Dokumenty z konferencií a plén (The Communist Party of Slovakia. Documents from the Conferences and Plenary Sessions). Pravda, Bratislava 1971, pp. 78-101. 
passage of the front. ${ }^{9}$ Due to the absence of the organisational structures of the Democratic Party, taking advantage of the persistence of their illegal Party structures from the war period, they easily mastered local politics represented by National Committees (národné výbory; regional and local political bodies integrating state and self-governing institutions). In the first months of 1945, the National Committees had 2/3 to 3/4 representatives consisting of their members with the Communists holding almost all chairmanship positions. The remaining members of National Committees were non-Communists, although the Communists accepted them. ${ }^{10}$ The situation slowly began to change when the leading persons of the Slovak Democrats from the Uprising reached the liberated east of Slovakia. Only then, at the beginning of 1945, the first regular organisations of the Democratic Party, established during the Uprising, started to form. Seemingly, the Democrats had the advantage of representing the rest of the political (non-left wing) spectrum. However, this potential advantage became evident much later. On the contrary, until autumn 1945, the organisational advantage, political initiative and favouritism of the Communist Party by the Soviet authorities was very apparent. On the other hand, the Democrats were defensive in almost everything, playing the role of a tolerated supplement of the more dominant Communists, as predicted by Gottwald and Husák ${ }^{11}$.

The help of the Soviet authorities in gaining Communist dominance in the liberated territory was manifested not only by arresting former representatives of the Ludák regime or its collaborators, but also by their imprisonment in Slovakia or their deportation to forced labour camps in the Soviet Union. Occasionally, the regional representatives of the newly created structures of the DS were intentionally arrested as well. This was often justified by a fabricated tale of their collaboration with the previous regime or even with the Nazis. ${ }^{12}$ Yet, the local Communists also used such groundless accusations to disqualify political competition. This resulted in the fear of any anti-Communist activities, often also deliberately substituted for anti-Soviet activities. The Soviet security authorities were particularly sensitive about that. Not always was there an intervention against the Slovak Democrats in the sense of their arrest or deportation. Sometimes, a display of antipathy, based

9 Zemplín manifestuje 14. januára za pôdu (Zemplín manifests 14 January for the land). Pravda, 7. 1. 1945, p. 2; Všetko za úplne vyhnanie Nemcov a za znovuvybudovanie Slovenska (Everything for completely driving out the Germans and rebuilding Slovakia). Pravda, 1. 3. 1945, p. 1.

10 Slovenský národný archív (Slovak National Archive, hereinafter SNA), f. Ústredný výbor Komunistickej strany Slovenska - generálny tajomník (Central Committee of the Communist Party of Slovakia General Secretariat) (ÚV KSS - GT), k. (Box) 2119, Počet členov N[árodného]R[evolučného]V[ýboru] (Number of National Revolutionary Committee members); JABLONICKÝ, Jozef: Slovensko na prelome (Slovakia on the Cusp). Vydavatelstvo politickej literatúry, Bratislava 1965, p. 198.

11 Gustáv Husák (1913-1991) at the given time the Commissioner of Interior in the Slovak self-government and the actual leader of the Communist Party of Slovakia. Intellectually and practically more important than the formal Slovak party chairman Karol Šmidke.

12 Compare for example ŠUTAJ, Štefan: Občianske politické strany v rokoch 1944 - 1948 (Civic Political Parties in 1944-1948). Veda, Bratislava 1999, s. 45-47. 
on a hearsay of local Communists, of a local Soviet commander towards a DS representative in the National Committee was more than enough. Thus, the Democrats understood that they need to quietly replace such people with persons less irritating for the Communists. ${ }^{13}$ However, these phenomena took place mainly in Eastern Slovakia at a time of minimal authority and the unstable position of the Czechoslovak authorities, or rather the Slovak National Council. It was also the case of the southern territories, occupied by Hungary during the war, where new state authorities were facing similar problems and Soviet authorities acted more arbitrarily. Gradually, however, as the front moved away from Slovakia, and the Czechoslovak authorities got restored everywhere, the SNR and the national committees took over the administration of the territory from the initial Soviet military administration ${ }^{14}$ and cases of arbitrary Soviet intervention became isolated. However, they had met their political goal. Only a few persons were able to resist the local Communists and protest, for example against the inadequate position of the Democrats or non-party members of the national committees, against the purposeful arrest of inconvenient people, against radical solutions leading to planned legal measures in terms of land reform, personnel cleansing of public offices, etc.

After the relocation of the highest Slovak bodies from Košice to Bratislava, or of the Czechoslovak government to the liberated Prague, much changed. The influence of the Soviet army and security bodies was minimal. The legality, order and disciplined reconstruction of the country became priorities. The post-war tasks were too great for the Communists to realise the need for a "controlled revolution". At first, the most pressing issues of that time had to be solved (securing basic food supply and its fluent distribution, preventing the country's sanitary collapse, rebuilding traffic infrastructure and destroyed buildings, cleansing the society of war criminals and ensuring population security, solving the issue of disloyal minorities, management of promised social reforms without jeopardizing the economic stability of the state, etc.). Until the autumn of 1945, when the first wave of basic social and economic renovation successfully took place, the Communists and the Democrats were able to agree without major problems on the fundamental changes characterising the post-war era - nationalisation of large and enemy manufactures, land reform, and retribution, punishment of the German and Hungarian minorities, or building of a national state. In the case of Slovakia, however,

13 Štátny archív Banská Bystrica, pobočka Velký Krtíš (State Archive Banská Bystrica, branch Velký Krtîš hereinafter ŠAP Velký Krtís), f. Okresný národný výbor (National County Committee) (ONV) Modrý Kameň, Zasadnutia ONV (Meetings of the ONV), year 1945.

14 The takeover of the country's civil administration from the initial post-frontal military administration of the Soviet army was based on the Czechoslovak-Soviet agreement about the administration of the liberated territory of 8 May 1944. According to the agreement, the front facilities to a depth of about 50-70 km fell within the competence of the Red Army authorities. Only beyond this zone could the Czechoslovak authorities carry out political administration. For the text of the agreement, see KLIMEŠ, Miloš - LESJUK, Petr - MALÁ, Ivana - PREČAN, Vilém: Cesta ke Květnu (The Path to May). Československá akademie věd, Praha 1965, pp. 125-126. 
new laws were prepared in this period, which later caused controversy regarding their interpretation and their implementation.

The land reform was the first major breaking point. It took away the ownership of land from all Germans and collaborators (or protégés of the L'udák regime), or in the case of Hungarians the land of more than 50 hectares, giving it to the hands of the Slovaks (or Slavic population) to the level of 8 or 13 hectares on average per owner. ${ }^{15}$ The reform was based on the proposal of the DS, which was sort of a successor of the Agrarian Party in the new post-war conditions, controlling the agrarian sector. Of course, the Communists had no problem with this rather revolutionary proposal. The conflicts started only during the early implementation of this regulation, when many local Communists understood this regulation as the arbitrary occupation of "manorial" land and its uncontrolled handing over to any person interested, preferably to less-wealthy persons, or to the supporters of the KSS. It started the conflict between the central authority of the Provisional Ministry of Agriculture and Land Reform, controlled by the Slovak Democrats, and local national committees or agricultural commissions, controlled by the Communists. ${ }^{16}$

Similar issues in different interpretation of post-war reforms and laws also arose during the creation and implementation of the retribution regulation of the SNR. Slovak Democrats and the Communists were united by a common desire to adopt their own Slovak standards in this matter, which would more widely respect the Slovak specifics of collaboration and resistance, before the adoption of the state-wide presidential decree. The strict implementation of the forthcoming presidential decree would result in the imprisonment or exclusion from public service of nearly all the representatives of the wartime Ludák regime. This would also affect thousands of resistance representatives in Slovakia, not excluding the highest democratic and communist representatives. Slovak collaboration and resistance reality during the war was fundamentally different from the Nazi occupation in the Czech lands. Therefore, the Slovak Communists and Democrats agreed relatively easily on the need for greater individualisation of the guilt of every single Slovak State public official, in particular putting focus on his attitude towards resistance and the Uprising. ${ }^{17}$ However, the harmony between the KSS and the

15 Nariadenie Slovenskej národnej rady č. 4/1945 (Regulation of the Slovak National Council No. 4/1945), 27. 2. 1945. Sbierka nariadení SNR, 1945, č. 1.

16 Compare Stenografický zápis 4. schôdze pléna Slovenskej národnej rady z 5. júna 1945 (Stenographic Minutes of the $4^{\text {th }}$ meeting of the plenary of the Slovak National Council of 5 June 1945). Slovenská národná rada, Bratislava 1945, pp. 12-24; CAMBEL, Samuel: Slovenská agrárna otázka 1944 - 1948 (The Slovak Agrarian Question 1944-1948). Pravda, Bratislava 1972, p. 295; KVETKO, Martin: Kto sabotuje pozemkovú reformu (Who Sabotaged the Land Reform). Ústredný sekretariát Demokratickej strany, Bratislava 1946, pp. 3-10.

17 Compare RAŠLA, Anton: L'udové súdy v Československu po II. svetovej vojne ako forma mimoriadneho súdnictva (People's Courts in Czechoslovakia after WWII as a form of extraordinary justice). Vydavatel'stvo Slovenskej akadémie vied, Bratislava 1969, pp. 43-47; JECH, Karel - KAPLAN, Karel (eds.): Dekrety prezidenta republiky 1940-1945. Dokumenty (Decrees of the President of the Republic 1940-1945. Documents), I. část. ÚSD AV ČR - Doplněk, Praha - Brno 1995, pp. 249-254 and 261-265. 
DS ended. As early as during the preparation of the retribution regulation of the Slovak National Council, the Communists tried to implement statutes on the cooperation of the defence lawyer with the court in proving the guilt of the accused. They also enforced the largest possible representation of laymen in the retribution judiciary instead of experts in law, etc. ${ }^{18}$ Although, the Democrats succeeded in refining some of the Communists' radical views in the end, and the resulting retribution standard of the SNR ${ }^{19}$ largely resulted from a political compromise, its implementation soon caused further conflicts. The Democrats stressed the need to judge each case strictly but fairly. The Communists, on the other hand, often followed Gottwald's recommendations - using retribution as important means of "cutting off" as many rotten "branches" of the bourgeoisie as possible..$^{20}$ They often desired to sentence not only those who were active collaborators with the Nazis, but also those opposing the post-war rise of the Communists while being haunted by their own wartime "sins". Thus, in the tactics of Slovak Communists, the retribution served not only to disqualify the obvious perpetrators of the previous regime, but also to intimidate real or potential opponents of post-war communisation of society or to exclude them from public life. In general, the Communists tried to enforce very strict retributive sentencing (often differentiated according to social class).

The relationship between the Slovak Communists and Democrats, but also between the Slovak and Czech Communists, reached their pivotal moment in the summer or autumn of 1945 . The relative symbiosis between the DS and the KSS was shaken for the first time by the Communist resistance in the issue of the nationalisation of education system, resulting in the first resolute intervention by the Communist-dominated Provisional Ministry of Interior against the opposing Catholic hierarchy and activists. ${ }^{21}$ The decisive factor, however, was the abandonment of the hitherto united national front of the SNR, demanding the federalisation of the state. This first serious conflict, in terms of achieving common insurgent and post-war goals of the Slovak Communists and the Slovak Democrats, occurred during the preparatory negotiations on the so-called First Prague Agreement between the leaderships of the Czech and Slovak Communists. ${ }^{22}$

18 L'udové súdy budú vykonávatelmi práva (People's Courts will be the executioners of law). Čas, 27. 5. 1945, p. 2; CAMBEL, Samuel: Revolučný rok 1945 (The Revolutionary Year of 1945). Stredoslovenské vydavatel'stvo, Banská Bystrica 1965, p. 104; FEIERABEND, Karel Ladislav: Pod vládou národní fronty (Under the Rule of the National Front). Vlastním nákladem (Self-published), Washington 1968, p. 44.

19 Nariadenia SNR č. 33/1945 (Regulations of the SNC Nr. 33/1945). Sbierka nariadení Slovenskej národnej rady, 1945, pp. 42-46.

20 VARTÍKOVÁ, Marta (ed.): Komunistická strana Slovenska. Dokumenty z konferencií a plén, p. 144.

21 See more PETRANSKÝ, Ivan A.: Štát a katolícka cirkev na Slovensku 1945 - 1946 (The State and Catholic Church in Slovakia, 1945-1946). Garmond, Nitra 2001, pp. 48-63.

22 Political agreement adopted on 2 June 1945 between the Slovak National Council and the central Czechoslovak government based on unequal federalisation of the state as it was created after the Slovak National Uprising (with the semi-autonomy for the Slovak national political bodies). KSS 
Although the KSS officially acted as an independent political party, in reality it was always subordinate to the Communist Party of Czechoslovakia and obeyed the directives of the Prague centre. The external form of party independence was preserved only for tactical reasons to achieve a more significant representation of the Communists in the initial proportional representation of political parties in the post-war government, Parliament or the National Front (Národný front).$^{23}$ In this manner, the Czech and Slovak Communists gained one third of the posts available among 6 existing political parties. If they formally acted as one party, they would occupy only a fifth of all posts. Slovak Communists such as Gustáv Husák or Ladislav Novomeský ${ }^{4}$ and others (later purposefully accused of bourgeois nationalism) fully respected the Party discipline and considered themselves the Slovak part of the united KSČ as early as during the Uprising and the post-war period, when the Košice Government Programme (the programme of the first after-war government from April 1945) was adopted. They were aware of this when the young insurgent chairmanship of KSS received a directive from Moscow, while also naturally respecting the authority of Gottwald, preferred by the Soviets. Gottwald and the Czech leaders of the KSČ pragmatically chose non-insurgent representatives of the Communist Party of Slovakia Viliam Široký and Július Durišš ${ }^{25}$ as their closest Slovak comrades in Prague. They were closer to them by age and by mentality. The Czech leaders of the KSČ wanted someone with the same experience in party policy and tactics prior to the war. They knew that Viliam Široký and Július Duriš also understood the post-war need to manoeuvre their political strategies somewhere between democracy and Communism, and they would be grateful for their governmental posts given to them despite not having a successful resistance past as insurgent Communists. On the contrary, the insurgent Communists worried Gottwald and Kopecký26, because they pushed for the federalisation of the state and a cooperation with their partners from the Uprising in the adoption of socialisation legislation. ${ }^{27}$ The conflicts deepened after the central government

preferred more competences for the SNR as the central Czechoslovak leadership of the KSČ, which enforced the Prague point of view in this matter.

23 Soon after the war, all political parties had to become part of a coalition system called the National Front. Outside this system, no other political party could legally exist. Except Slovak and Czech communist parties, there were also Slovak Democrats in Slovakia, as well as Social Democrats, Christian Democrats and National Socialists in the Czech lands.

24 Ladislav (Laco) Novomeský (1904-1976), one of the three most important leading persons of the Communist Party in the illegal Slovak National Council from 1943 (K. Šmidke, G. Husák, L. Novomesky). After the war, he served as the Minister of Education in the Slovak provisional government.

25 Leading persons of the inter-war Communist Party in Slovakia or in the first years of the wartime period, with no exact Slovak national orientation, but very close relations to the central Prague party leadership.

26 Václav Kopecký (1897-1961), a close collaborator with Klement Gottwald, leading exile representative of the KSČ in Moscow during WWII and Minister of Culture in the post-war period, a known firm Czech nationalist.

27 Compare PEŠEK, Jan: Komunistická strana Slovenska. Dejiny politického subjektu (The Communist Party of Slovakia. The History of the Political Subject), I. diel. Veda, Bratislava 2012, pp. 22-41; MACHÁČEK, Michal: Gustáv Husák. Vyšehrad, Praha 2019, pp. 185-211. 
took power in Prague with the first conflicts over the competencies of ministers and provisional ministers appearing right away. The conflicts were often between Communist ministers and Democratic provisional ministers. Reports from Slovakia about the issues of the Slovak chairmanship represented by Šmidke ${ }^{28}$ and Husák with the development of the "people's democratic" revolution emerged. The Slovak Democrats became more determined to criticise Communist mistakes in the first months of the post-war regime, mainly in Eastern Slovakia (arbitrary arrests, often false accusations, land parcelling, totalitarian practices in national committees, etc.), especially after the first "stabilising" manifestative national congress of the Democratic Party in Martin in early July 1945. In addition, the Prague headquarters of the KSČ received reports from unsatisfied radicals within the KSS accusing leaders of their own party of a docile policy towards the Democrats ("the reaction raises questions..."), reaction not resolute enough against the opponents of the nationalisation of the educational system, and accusing the Party of being afraid to enforce a harsher retribution and land reform. Both non-insurgent Slovak Communists - Deputy Prime Minister Široký and Minister of Agriculture Ďuriš worked mainly towards furthering their own careers and power. They personified the "problems of the revolution" in Slovakia and pointed out that current leaders of the KSS are young and inexperienced and not able to handle such tactically demanding tasks. Gottwald and the Czech KSČ leadership were most annoyed by the fact that the Slovak Communists participated in the preparation and implementation of the regulations of the SNR, which did not correspond to the tactics of the KSČ in the Czech lands. In particular, there was a different regulation of national reports of confiscated or nationalised companies and trades. ${ }^{29}$ In the end however, it was the Slovak question which started the punitive reaction towards the Slovak chairmanship of the KSS. Shortly before the main negotiations on the adjustment of the relationship between the central government and the SNR (the so-called First Prague Agreement), Gottwald firmly explained to the former insurgent chairmanship represented by Šmidke, Husák and Novomeský that the federalisation of the state, which had been demanded to be included in the negotiations with the Prague government by the directives of the SNR plenum, would not be included..$^{30}$ Any rigorous solution of Slovakia's position within the state was postponed. It was necessary to focus more on the priorities, such as the socialisation and gain of power and not to allow the Czech non-Communists to get the better of the Communists by pointing out the separatism of Slovak Communists and the dual approach to the state policy of the Communists in the Czech lands and Slovakia.

28 Karol Šmidke (1897-1952), member of the Czechoslovak parliament for the KSČ in the interwar era, sent from Moscow exile to Slovakia to lead the KSS in 1943. In 1944-1945 co-chairman of the Slovak National Council and the chairman of the KSS.

29 ČERNÁK, Tomáš - SYRNÝ, Marek: Husák. Vrcholy a pády 1945 - 1951 (Husák. Peaks and Falls 19451951). Marenčin PT, Bratislava 2018, pp. 72-83.

30 Archiv Masarykova ústavu (Archive of the Masaryk Institute), f. Edvard Beneš III., sign. P 60/5. 
The Slovak Communists understood this very quickly and, during the negotiations of the government with the SNR, they obediently defended the need to preserve the previous competencies of the Slovak national authorities without their clear legal anchoring or deepening of their governmental autonomy. ${ }^{31}$

Occasional arbitrary behaviour of the "insurgent" chairmanship of the KSS at the time was individually disciplined in August 1945. The KSČ headquarters in Prague "ordered" the Bratislava chairmanship to organise an all-Slovak congress of the KSS in Žilina, where the Chairman of the KSS, Karol Šmidke was forcibly replaced by Viliam Široký who was closer to Gottwald and the Prague centre. Gustav Husák also lost the power-important office of Provisional Minister of Interior in the re-established Board of Provisional Ministers. He was transferred to a less important office of Provisional Minister of Transport. After the replacement of the former insurgent chairmanship of the KSS by Široký and "his people", the majority of the disproportions between the goals and tactics of the KSS and the KSČ disappeared. Širokýs new chairmanship of the KSS had already fully synchronised its political steps with the intentions and policies of the KSČ. Instead of slogans about the political equality of Slovakia and the Czech lands through federalisation (the principle of "equal to equal"), a propaganda campaign was launched on the economic equalisation of Slovakia with the regions behind the River Morava.

Since autumn 1945, Široký's new chairmanship of the KSS focused on the propagandistic persuasion of the Slovaks about the benefits of the Communist dominance in the country which would ensure both better overall economic functioning and social equality in the state, as well as a more equal position of Slovakia and the Slovaks. The relocation of the redundant machines and companies from the depopulated Czech border territory to less industrialised areas of Slovakia should demonstrate the help of the more developed Czech lands to Slovakia on a practical level. Propaganda was one thing, but the reality was much more modest. Instead of relocation of the "companies" to Slovakia, the Slovaks were often forced to move to the Czech border territory because of free capacities. Naturally, it had a completely different impact on the solution of the economic and social equalisation of the East and the West of the Czechoslovak Republic than what the Communists had originally proclaimed.

However, Širokýs new chairmanship was quite innovative in the fight for power against the competing DS. Supplemental elections to national committees took place in autumn 1945 and the Communists clearly "got the short end of the stick". The membership of the DS was constantly growing and by the end of 1945 they had more members than the KSS (even with the worse organisation of the farm-

31 See more KAPLAN, Karel (ed.): Pražské dohody 1945-1947 (Prague Agreements 1945-1947). ÚSD ČSAV, Praha 1992, pp. 28-44; PREČAN, Vilém: Záznam o zasedání Ústředního výboru KSČ 17. a 18. července 1945 (Record of the meeting of the Central Committee of the KSC 17 and 18 July 1945). In: Česko-slovenská historická ročenka. Česko-slovenská / Slovensko-česká komisia historikov, Brno 1997, pp. 203-300. 
ers as the main member base of the Democrats). On the other hand, the Communists stagnated. ${ }^{32}$ Therefore, Viliam Široký and his people decided not to wait passively for the election results in the planned parliamentary elections of May 1946 but started a precautionary strike against the DS with the aim to disrupt this large non-Communist party, occupying the entire centre-right political spectrum. The idea of an active support of the faction of political Catholicism within the Democratic Party, dominated mostly by Protestant leaders from the times of the Uprising, was born. In addition to the supporters of political Catholicism (who distanced themselves from the wartime HSL'S, but not from promoting the interests of the Catholic Church in the post-war society), the Communists also targeted dissidents from strictly Czechoslovak-oriented functionaries of the DS, who found the Slovak Democrats' leadership policy too national. They feared that the idea of federalising the state would lead to its disintegration. ${ }^{33}$ On the eve of 1945 , both of these internal fractions of the DS decided to create a new joint political party aimed at Catholic voters but with a good political "coverage" arranged by the rebelling Czechoslovak-oriented Catholic functionaries of the DS.

\section{Communist Party of Slovakia and the 1946 elections}

In early 1946 everything seemed to be going very well for the Communists. It was not very difficult to ensure the acceptance of a new party of political Catholicism in the Slovak National Front with the support of the KSS. Even the strictest adherents of political Catholicism were able to adapt to the post-war limits within their political programmes, when all parties had to "conform" to the postulates of the Košice government programme. Gradually, however, achieving the vision of an independent political party uniting dissatisfied Catholics inside and outside the DS became more and more complicated as the leadership of the KSS needed to be sure of the smooth cooperation of the new party. Demands for ever greater expressions of solidarity between the newly formed party with the people's democratic regime and for personnel exchanges in the leadership of this party (strengthening the

32 NA ČR, f. 100/24, sv. 41, a. j. 834; SNA, f. ÚV KSS - GT, k. 2126; BARNOVSKÝ, Michal: Sociálne triedy a revolučné premeny na Slovensku v rokoch 1944 - 1948 (Social clases and revolutionary transformations in Slovakia in 1944-1948). Veda, Bratislava 1978, pp. 199-200. In August 1945 DS had about 180,000 party members, in March 1946 about 245,000. KSS, in August 1945, had about 168,000 party members, but from autumn 1945 to spring 1946 it was still about 200,000 and it only changed in the beginning of the 1948. SYRNÝ, Marek: Slovenskí demokrati '44 - 48 (Slovak Democrats '44-48). Múzeum SNP, Banská Bystrica 2010, pp. 91-92; BARNOVSKÝ, Michal: Sociálne triedy a revolučné premeny na Slovensku v rokoch 1944 - 1948, pp. 181-204.

33 See more ČELKO, Vojtech: Demokratická strana a jej miesto v slovenskom politickom živote v rokoch 1944 - 1946 (The Democratic Party and its place in Slovak political life in 1944-1946) (IX). L'ud, 7. 2. 1990, p. 2; BARNOVSKÝ, Michal: Politické strany na Slovensku a problém politického katolicizmu v rokoch 1945 - 1946 (Political parties in Slovakia and the problem of political Catholicism in 19451946). In: Československo na rozhraní dvou epoch nesvobody. Národní archiv - ÚSD AV ČR, Praha 2005, pp. 74-76; ŠUTAJ, Štefan: Občianske politické strany v rokoch 1944 - 1948, pp. 110-114. 
Czechoslovak line at the expense of political Catholicism) came from the Slovak National Front (especially from the KSS leadership). There were also contradictions between the people's Catholic movement and the Communists (e.g., the so-called cross badge movement). On the one hand, the Communists thus tried to gain favour of the "dissent" among Slovak Democrats, on the other hand, they did not withhold any sign of strong disapproval when the promoters of the new party imagined its social impact differently than the Communists. In the end, the opposition in the DS mostly realised what role the new party would play in the tactics of the KSS. That the existence of non-Communist politics would be in jeopardy; the Communists could win the election and then use one non-Communist party against the other and gradually liquidate both. ${ }^{34}$ Most of the activists involved in the formation of the new party therefore decided to accept the offer of the former DS leadership. They remained active within the structures of the Slovak Democrats on the basis of the so-called April Agreement, according to which a confessional key was used in redistributing power in the party in a 2:1 ratio in favour of the Catholics.

Thanks to the April Agreement, the Slovak Democrats decisively defeated the KSS in the May parliamentary elections. They won up to $2 / 3$ of all Slovak votes, while Slovak Communists gained more than $30 \%$. The other two new parties, formed three months before the elections, addressed roughly $3 \%$ of voters each.$^{35}$ Neither the Freedom Party (Strana slobody) as a potential Trojan horse of the communist strategy to dissolve the DS, gaining electoral support by emphasizing political Catholicism, farmer and Slovak questions, ${ }^{36}$ nor the Labour Party (Strana práce), as the Slovak branch of the Czechoslovak Social Democratic Party (Československá strana sociálně-demokratická), ${ }^{37}$ changed the preferences of Slovaks significantly. They were already clearly decided to choose the conservative DS or the revolutionary KSS. Although sparks flew between the Slovak Democrats and the Communists as early as during the election campaign (apart from the countless press, leaflet or manifestation appeals to DS for maintaining the political, economic and religious freedom and democracy,,$^{38}$ and to KSS for a more revolutionary solution to the social issue; insults of individual supporters of both camps were occasional ${ }^{39}$ ), the

34 Compare for example STAŠKO, Jozef: Slovensko po druhej svetovej vojne (Slovakia after WWII). Good Books, Cambridge 1977, pp. 26-28.

35 Štatistická príručka Slovenska 1947 (Statistical handbook of Slovakia 1947). Štátny štatistický a plánovací úrad, Bratislava 1947, pp. 307-309.

36 For more see ŠUTAJ, Štefan: Občianske politické strany v rokoch 1944 - 1948, pp. 136-142.

37 HLAVOVÁ, Viera: Sociálna demokracia na Slovensku v rokoch 1945 - 1948 (Social Democracy in Slovakia in 1945-1948). In: Kapitoly z dejín sociálnej demokracie na Slovensku (Chapters from the history of social democracy in Slovakia). T.R.I. MÉDIUM, Bratislava 1996, pp. 312-318.

38 Čo chceme? (What do we want?) Čas, 12. 5. 1946, p. 3; SNA, f. Demokratická strana (Democratic Party) (DS), k. 11.

39 SNA, f. ÚV KSS - GT, k. 2150, Ohlas vysokoškolákov - Svoradovské chodby skropené krvou (University students' response - Svoradov corridors sprinkled with blood), undated, and Správa s. Kubača o vražde predsedu KSS v Čáre v predvolebnom období (Comrade Kubač's report on the murder of the 
elections were peaceful and fair. But the victory of the Democrats the unexpectedly high defeat of the Communists in Slovakia triggered a huge rescue mechanism among their Slovak and Czech sponsors. From the initial proposals of a forceful solution (prevalent among pro-Communist former partisans or Communists in the security forces) and the enforcement of the exclusion of democrats from the National Front, the KSS and KSČ leaderships gradually shifted to more sophisticated tactics. They tried to portray the DS as a former insurgent party that left the majority top positions within the party to former Ludáks and collaborators in exchange for the electoral victory over progressive Communism. Thus, the DS became not only unreliable, but according to Communists, if the central government would not intervene immediately, there was even a risk of a new separation of Slovakia from the Czech lands, as the public authorities in Slovakia will be controlled by neo-Ludáks in the DS.40

Czech non-Communist parties were easily persuaded by the hysterical outbursts of Communists about the threat to the Czechoslovak Republic from Slovakia to convince them of the need for greater control and subordination of the Slovak national authorities to the central government. In fact, some Czech military units were immediately relocated to Slovakia, ${ }^{41}$ and later the army counterintelligence headquarters in Prague began to perceive Slovakia as an "enemy zone" that must be significantly infiltrated and monitored. ${ }^{42}$ Soon after the elections, a special committee under the Communist-controlled Ministry of Interior released a "shocking" report on the course of the election campaign and elections in Slovakia. Its purpose was to prove the enormous influence of "former wartime authorities" on the winning campaign of the DS. In addition to the legalization of Ludáks and their establishment, the democrats were also publicly blamed for alleged attacks on the alliance with the USSR, on the people's democratic regime on the Czechs and, vice versa, for favouring the Slovak State, etc. ${ }^{43}$ Of course, the authors of the report did not mind at all that the overwhelming majority of these allegations came directly from communist organisations or social organisations sympathising with KSS and not from regular police reports. The hysteria caused by the Communists over the

KSS chairman in Čáry in the pre-election period), 23. 5. 1946; Na okraj pripravených štvaníc v Starej Lubovni (On the edge of the arranged chasing in Stará Lubovňa). Demokrat, 15. 5. 1946, p. 2.

$40 N A \check{C} R$, f. 100/24, sv. 140, a. j. 1494, Zapis 60. schodze vlady (Minutes of the 60th government meeting), 27. 5. 1946.

41 BARNOVSKÝ, Michal: Na ceste $k$ monopolu moci (On the Way to a Monopoly of Power). Archa, Bratislava 1993, s. 106.

42 Vojenský ústřední archiv - Vojenský historický archiv (Military Central Archive - Military Historical Archive) (VÚA - VHA) Praha, f. Vojenská kancelář prezidenta republiky (Military Office of the President of the Republic), k. 7, Zvláštní přehled zpráv č. 2 (Special Overview of the Reports No. 2), 6. 12. 1946; HANZLÍK, František: Velitelský sbor Čs. armády na Slovensku jako objekt zájmu Vojenského obranného zpravodajství v letech 1945-1948 (General HQ of the Czechoslovak Army in Slovakia as an object of the interest of Military Defence Intelligence in 1945-1948). In: Vojenská história, 1999, Vol. 3, No. 4, p. 64.

$43 N A \check{C} R$, f. 100/24, sv. 41, a. j. 839, Souhrnná správa komise ministerstva vnitra (General Report of the Ministry of the Interior Committee), 4. 6. 1946. 
election results in Slovakia ${ }^{44}$ gathered success, especially in the form of adoption of the so-called Third Prague Agreement (27 June 1946), which made the Slovak national authorities (the Board of Commissioners, the Slovak National Council, the Supreme Control Court, etc.) de facto subordinate institutions of the government, or rather central national authorities ${ }^{45}$ Although the results of the elections in Slovakia were formally acknowledged and the Democrats had a two-thirds majority in the Board of Commissioners or in the SNR, any executive or legislative independence of the Slovak national authorities in fact ceased to exist.

\section{The milestone year of 1947 and the decision of power in February 1948}

In such a stalemate, the Slovak Communists were able to endure for about half a year. Then, in the spring of 1947, they came up again with the idea of an overall attack on the positions and authority of the Democratic Party. The DS still controlled most national committees and public institutions, and any significant effort by the Communists to endorse pro-communist solutions to social problems in Slovakia was thus paralysed. The previous year's effort to split the huge non-Communist DS and bring about a more significant outflow of its Catholic supporters was resumed. The trial with the former President of the Slovak State, Catholic priest Jozef $\mathrm{TisO}^{46}$, seemed perfect for this purpose. The leadership of the Slovak and Czech Communists rightly assumed that Catholics in the DS expected their party leadership, dominant in Slovakia, not to allow the capital punishment for Tiso to be carried out, and the National Court, subject to the SNR, would commute the death penalty requested by the state prosecutors. The Slovak Communists therefore passionately embarked on creating social and political pressure for Tiso to be punished as severely as possible. ${ }^{47}$ Democrats, on the other hand, sought to have the court take into account the differences in responsibility for the wartime regime between the conservatives led by Tiso and the radicals led by former Prime Minister Vojtech Tuka or the Minister of Interior and Commander of the Hlinka Guard $^{48}$, Alexander Mach. However, the Communists could not accept such differentiation and relied mainly on the strident opinions and political views of the

44 See for example Socialistická väčšina v štáte - záruka pokrokového vývinu (Socialist Majority in the State - a Guarantee of Progressive Development). Pravda, 1. 6. 1946, p. 1; KSS za jednotnost' a bezpečnost štátu (KSS for the unity and security of the state). Deň, 14. 6. 1946, p. 1.

45 Compare BARNOVSKÝ, Michal: Na ceste k monopolu moci, p. 46.

46 Jozef Tiso (1887-1947), although more of a conservative politician, was considered the main culprit within the wartime puppet regime in Slovakia as the person responsible for the Slovak State politics in 1939-1945 (President and the chairman of Hlinka's totalitarian Slovak People's Party) collaborating with Nazi Germany.

47 Compare $N A C \breve{C}$, f. 100/24, sv. 143, a. j. 1494, 71. schôdza vlády (71st government meeting), 21. 3. 1947, p. 26.

48 Paramilitary organisation formed by the HSL'S unifying the most radical members of the Slovak wartime society, a Slovak equivalent of the Nazi Sturm Abteilung (SA). 
Tribunal President Igor Daxner ${ }^{49}$. He ignored all the pleas of the SNR presidium controlled by the Slovak Democrats that it must be kept informed of the progress of the trial and that a verdict must be politically agreed upon. On the other hand, Daxner deliberately accepted the exclusion of Mach from the trial for his alleged health issues. ${ }^{50}$ When the Daxner-led tribunal sentenced Tiso to death, the government was to vote in favour of a pardon (based on the recommendations of the SNR presidium) and President Beneš was to make the final decision on whether the pardon will be awarded or rejected. At that time, the Communists were able to organize delegations of former partisans and trade unionists not only coming to Bratislava, but even attending a government meeting in Prague, just for the pardon to be rejected. ${ }^{51}$ Not even after the execution of Tiso did the status quo desired by Communists arise and the DS remained almost as internally strong as before.

However, it all changed with political and social pressure in the summer and autumn of 1947. At that time, the Slovak and Czech Communists took advantage of the economic problems in the summer of 1947 (drought, crop failure, supply issues, etc.) and the staged revelation of illegal "Ludák" groups to form a general attack against the Democratic Party. The anti-state conspiracy in Slovakia pompously "revealed" in the government and communist press (interconnecting the Ludák exile, the small domestic illegal opposition, the reaction of the Democratic Party and even among the Banderites ${ }^{52}$ ) was combined with economic problems the blame for which was put on the "reaction", i.e. groups not connected to the KSS and its satellite organisations. ${ }^{53}$ The pressure from the Communists in the government, parliament and National Front escalated by the ultimatum-like demands of the union of partisans and trade unions for personnel purges ${ }^{54}$ based on the lists prepared by the Communists. They also demanded the resignation of DS

49 Igor Daxner (1893-1960), was former member of the Czechoslovak Social Democratic Party (ČSSD), from 1944 a member of the KSS. After the war, he served as the President of the National Tribunal for war crimes, and politics, known mostly for his strict judgment passed against the representatives of the collaborating Slovak State.

50 HRUBOŇ, Anton: Alexander Mach. Radikál z povolania (Alexander Mach. Radical by profession). Premedea, Bratislava 2018, pp. 373-374.

51 For more see KAPLAN, Karel (ed.): Dva retribuční procesy (Two Retributive Trials). ÚSD ČSAV, Praha 1992, pp. 225-252.

52 Members of the anti-Soviet nationalistic Ukrainian Insurgent Army trying to escape in small groups from the pressure of the Polish security units in South-Eastern Poland through Czechoslovakia to Bavaria, controlled by the USA, where they expected a more liberal attitude towards their wartime and post-war activities than in Poland or Soviet Ukraine.

53 SNA, f. Úrad predsedníctva Slovenskej národnej rady (Bureau Office of the Slovak National Council) (ÚP SNR), k. 1000, Stenografická správa o 85. schôdzi parlamentu (Stenographic minutes on the 85th parliamentary meeting), 11. 12. 1947, pp. 60-62; Ibid., Stenografická správa o 72. schôdzi parlamentu (Stenographic minutes on the 72nd parliamentary meeting), 18. 9. 1947, pp. 13-14.

54 For example, see LETZ, Róbert: Partizáni ako politický a mocenský činitel na Slovensku v rokoch 1945 - 1948 (Partisans as a political and power actor in Slovakia in 1945-1948). In: Dies Ater Neštastný deň 29. 8. 1944 (Dies Ater -Unhappy day 29. 8. 1944). Lúč, Bratislava 1994, pp. 36-38; BARNOVSKÝ, Michal: Na ceste k monopolu moci, pp. 210-211. 
commissioners managing economic departments ${ }^{55}$ (they were allegedly responsible for the issues in their departments or were even deliberately causing them only to discredit the people's democratic regime). ${ }^{56}$ Two of the three Secretaries General of the DS (Jan Kempný, Miloš Bugár), who were extradited by parliament as members of the parliament, were also blamed in the fabricated conspiracy by the State Security (Štátna bezpečnost', ŠtB). All this resulted in a government crisis in Slovakia, concocted by the KSS leadership and carried out with the use of communist control over the leadership of trade unions. Gustáv Husák, as the Chairman of the Board of Commissioners, and his fellow Communists in the Board resigned on the basis of the trade union demands. ${ }^{57}$ The government crisis, lasting three weeks, had to be finally resolved by the intervention of Prime Minister Gottwald. But not even he could persuade the Slovak Democrats (who now had the support among the Czech non-Communists in the government) to accept all the personnel demands of the KSS in the reconstructed Board of Commissioners. Although the Democrats eventually lost the majority in the Board at the expense of the smaller non-Communist parties, the Communists did not improve their status by a single post. And the Department of Agriculture, so crucial to the Democrats, remained under their administration. ${ }^{58}$

The autumn stalemate in the decision of power between the Democrats and the Communists in Slovakia thus remained unresolved until February 1948. At this point, it is necessary to draw attention to least some specifics of the Slovak "Victorious February". ${ }^{99}$ In comparison to the coup in Prague or the Czech lands, the coup in Slovakia was less of a legal act and more of a demonstration of force and an effort to induce fear. During the coup in Slovakia, armed groups of former partisans and Communists in the security forces oversaw the situation in favour of the Communists, controlled all strategic buildings and communications (telephone, telegraph, non-Communist press, etc.) and even ostentatiously transported the arrested lower DS officials on the streets. At the same time, reports and arrest warrants had already been published in the press and announced on radio stations. The Democratic Commissioners and the leadership of the DS were physically denied access to their offices. In fact, they lost any possibility of communication

55 Na čelo Slovenska nový Zbor povereníkov (A new Board of Commissioners at the head of Slovakia). Pravda, 1. 11. 1947, p. 1.

56 SNA, f. Povereníctvo vnútra - bezpečnostný odbor (Interior Commission - Security Department), k. 455, No. 11094/47; SNA, f. Povereníctvo vnútra - personálny odbor (Interior Commission Personnel Department), k. 11, No. 87/47.

$57 N A \check{C} R$, f. 100/24, sv. 41, a. j. 836, List predsedu zboru povereníkov G. Husáka predsedovi vlády K. Gottwaldovi (Letter from the Chairman of the Board of Commissioners G. Husák to the Prime Minister K. Gottwald), 30. 10. 1947.

58 Compare RÁKOŠ, Elo - RUDOHRADSKÝ, Štefan: Slovenské národné orgány 1943 - 1968 (Slovak national bodies 1943-1968). Slovenská archívna správa, Bratislava 1973, p. 500.

59 "Victorious February" is a communist propaganda euphemism for the thesis that, through the Communist Party, "victorious people" joined the government by pushing the communist-defiant democratic politicians out of government in February 1948. 
with subordinate bodies or the population, while constantly being threatened by the demonstration of force from Communists in an effort to induce fear of its possible employment. ${ }^{60}$

\section{Conclusion}

Summarising the policy and tactics of the Slovak Communists' power struggle between the liberation in 1945 and the gain of totalitarian power in 1948, we can say the following: the KSS very skilfully used all the available standard, less typical and even non-parliamentary/undemocratic ways of political battle.

On the one hand, the KSS used the traditionally purposeful party propaganda exaggerating its own programme and success as well as discrediting political opponents and their real or alleged mismanagement of the society. It often used purposeful political and social populism and voter corruption by improving or at least promising to improve the social status of preferred social groups. It also abused the political support and pressure of the KSČ to change the power-political situation in Slovakia. To "evoke pressure from the streets/vox populi", the KSS used mass social organisations loyal to the party. Last but not least, to gain power, it also used "renegades" in non-Communist parties to fragment and equalize the ability of those parties to act.

The formation of pro-Communist structures in individual central state and public institutions, pursuing an objective and carefully planned promotion of Communist party politics, can be placed somewhere between the usual and non-standard political practices.

On the other hand, there are examples of KSS policies, which were and still are perceived to this day as distorting democracy and parliamentary processes and which aim to gain political power at any cost, especially at the expense of political and personal freedom. Examples include the abuse of the influence of the Red Army and the revolutionary dominance of the KSS shortly after the liberation. Furthermore, the abuse of the retribution judiciary, security intelligence authorities, or the fabrication of false accusations and subsequent arrests, harsh investigations and later even kangaroo courts are also among the examples. And finally, a crucial demonstration of willingness to use force in resolving political disputes/power struggle, especially through Communist radicals in the security services and radicalised partisans should be mentioned.

60 MIŠEJE, František: Revolučnou cestou (Revolutionary Route). Ústav marxizmu-leninizmu ÚV KSS, Bratislava 1988, pp. 204-206; BARNOVSKÝ, Michal: Preberanie moci a pofebruárová očista 1948 (Seizing power and the post-February purge of 1948). In: BARNOVSKÝ, Michal (ed.): Od diktatúry $k$ diktatúre (From dictatorship to dictatorship). Veda, Bratislava 1995, pp. 89-90; KAPLAN, Karel: Pět kapitol o Únoru (Five Chapters on February). Doplněk, Brno 1997, pp. 524-526; PEŠEK, Jan: Februárový prevrat na Slovensku (The February Putsch in Slovakia). Soudobé dějiny, 1998, Vol. 5, No. 2-3, pp. 266-272. 


\section{BIBLIOGRAPHY}

\section{Archival sources}

Archiv Masarykova ústavu

f. Edvard Beneš III.

Národní archiv České republiky

f. Klement Gottwald (100/24)

Slovenský národný archív

f. Demokratická strana (DS)

f. Povereníctvo vnútra - bezpečnostný odbor

f. Povereníctvo vnútra - personálny odbor

f. Úrad predsedníctva Slovenskej národnej rady (ÚP SNR)

f. Ústredný výbor Komunistickej strany Slovenska - generálny tajomník (ÚV KSS - GT)

Štátny archív Banská Bystrica, pobočka Velký Krtíš

f. Okresný národný výbor (ONV) Modrý Kameň

Vojenský ústrední archiv - Vojenský historický archiv

f. Vojenská kancelář prezidenta republiky

\section{Secondary Literature}

BARNOVSKÝ, Michal: Na ceste $k$ monopolu moci. Archa, Bratislava 1993

BARNOVSKÝ, Michal: Politické strany na Slovensku a problém politického katolicizmu v rokoch 1945 - 1946. In: Československo na rozhraní dvou epoch nesvobody. Národní archiv - ÚSD AV ČR, Praha 2005, pp. 69-78

BARNOVSKÝ, Michal: Preberanie moci a pofebruárová očista 1948. In: BARNOVSKÝ, Michal (ed.): Od diktatúry k diktatúre. Veda, Bratislava 1995, pp. 88-96

BARNOVSKÝ, Michal: Sociálne triedy a revolučné premeny na Slovensku $v$ rokoch 1944 - 1948. Veda, Bratislava 1978

CAMBEL, Samuel: Revolučný rok 1945. Stredoslovenské vydavatel'stvo, Banská Bystrica 1965

CAMBEL, Samuel: Slovenská agrárna otázka 1944 - 1948. Pravda, Bratislava 1972 ČELKO, Vojtech: Demokratická strana a jej miesto v slovenskom politickom živote v rokoch 1944 - 1946 (IX). L'ud, 7. 2. 1990, p. 2

ČERNÁK, Tomáš - SYRNÝ, Marek: Husák. Vrcholy a pády 1945 - 1951. Marenčin PT, Bratislava 2018 
Čo chceme? Čas, 12. 5. 1946, p. 3

FEIERABEND, Karel Ladislav: Pod vládou národní fronty. Vlastním nákladem, Washington 1968

HLAVOVÁ, Viera: Sociálna demokracia na Slovensku v rokoch 1945 - 1948.

In: Kapitoly z dejín sociálnej demokracie na Slovensku. T.R.I. MÉDIUM, Bratislava 1996, pp. 312-330

HRUBOŇ, Anton: Alexander Mach. Radikál z povolania. Premedea, Bratislava 2018 JABLONICKÝ, Jozef: Slovensko na prelome. Vydavatel'stvo politickej literatúry, Bratislava 1965

JECH, Karel - KAPLAN, Karel (eds.): Dekrety prezidenta republiky 1940-1945.

Dokumenty, část I. ÚSD AV ČR - Doplněk, Praha - Brno 1995

KAPLAN, Karel (ed.): Dva retribuční procesy. ÚSD ČSAV, Praha 1992

KAPLAN, Karel (ed.): Pražské dohody 1945-1947. ÚSD ČSAV, Praha 1992

KAPLAN, Karel: Pět kapitol o Únoru. Doplněk, Brno 1997

KLIMEŠ, Miloš - LESJUK, Petr - MALÁ, Ivana - PREČAN, Vilém: Cesta ke Květnu.

Československá akademie věd, Praha 1965

KSS za jednotnost' a bezpečnost' štátu. Deň, 14. 6. 1946, p. 1

KVETKO, Martin: Kto sabotuje pozemkovú reformu. Ústredný sekretariát

Demokratickej strany, Bratislava 1946

LETZ, Róbert: Partizáni ako politický a mocenský činitel' na Slovensku v rokoch 1945 - 1948. In: Dies Ater - Neštastný deň 29. 8. 1944. Lúč, Bratislava 1994, pp. $31-40$

LIPTÁK, L'ubomír a kol.: Politické strany na Slovensku 1860 - 1989. Archa, Bratislava 1992

L'udové súdy budú vykonávatelmi práva. Čas, 27. 5. 1945, p. 2

MACHÁČEK, Michal: Gustáv Husák. Vyšehrad, Praha 2019

MIŠEJE, František: Revolučnou cestou. Ústav marxizmu-leninizmu ÚV KSS, Bratislava 1988

Na okraj pripravených štvaníc v Starej L'ubovni. Demokrat, 15. 5. 1946, p. 2 PEŠEK, Jan: Februárový prevrat na Slovensku. Soudobé dějiny, 1998, Vol. 5, No. 2-3, p. 266-274

PEŠEK, Jan: Komunistická strana Slovenska. Dejiny politického subjektu, I. diel. Veda, Bratislava 2012

PETRANSKÝ, Ivan A.: Štát a katolícka cirkev na Slovensku 1945 - 1946.

Garmond, Nitra 2001

PREČAN, Vilém: Záznam o zasedání Ústředního výboru KSČ 17. a 18. července 1945. In: Česko-slovenská historická ročenka. Česko-slovenská / Slovensko-česká komisia historikov, Brno 1997, pp. 203-300

RÁKOŠ, Elo - RUDOHRADSKÝ, Štefan: Slovenské národné orgány 1943 - 1968.

Slovenská archívna správa, Bratislava 1973 
RAŠLA, Anton: L'udové súdy v Československu po II. svetovej vojne ako forma mimoriadneho súdnictva. Vydavatel'stvo Slovenskej akadémie vied, Bratislava 1969 Socialistická väčšina v štáte - záruka pokrokového vývinu. Pravda, 1. 6. 1946, p. 1 STAŠKO, Jozef: Slovensko po druhej svetovej vojne. Good Books, Cambridge 1977 Stenografický zápis 4. schôdze pléna Slovenskej národnej rady z 5. júna 1945. Slovenská národná rada, Bratislava 1945

SYRNÝ, Marek: Slovenskí komunisti v rokoch 1939 -1944. Belianum, Banská Bystrica 2013

Štatistická príručka Slovenska 1947. Štátny plánovací a štatistický úrad, Bratislava 1947

ŠUTAJ, Štefan: Občianske politické strany v rokoch 1944 - 1948. Veda, Bratislava 1999

VARTÍKOVÁ, Marta (ed.): Komunistická strana Slovenska. Dokumenty z konferencií a plén. Pravda, Bratislava 1971

Všetko za úplne vyhnanie Nemcov a za znovuvybudovanie Slovenska.

Pravda, 1. 3. 1945, p. 1.

Zemplín manifestuje 14. januára za pôdu. Pravda, 7. 1. 1945, p. 2 